\title{
New Insights Concerning the Glucose-dependent Insulin Secretagogue Action of Glucagon-like Peptide-1 in Pancreatic $\beta$ - Cells
}

\author{
G. Holz \\ Department of Physiology and Neuroscience, New York University School of Medicine, USA
}

\begin{abstract}
The GLP-1 receptor is a Class B heptahelical G-protein-coupled receptor that stimulates cAMP production in pancreatic $\beta$-cells. GLP-1 utilizes this receptor to activate two distinct classes of cAMP-binding proteins: protein kinase A (PKA) and the Epac family of cAMP-regulated guanine nucleotide exchange factors (cAMPGEFs). Actions of GLP-1 mediated by PKA and Epac include the recruitment and priming of secretory granules, thereby increasing the number of granules available for $\mathrm{Ca}^{2+}$-dependent exocytosis. Simultaneously, GLP-1 promotes $\mathrm{Ca}^{2+}$ influx and mobilizes an intracellular source of $\mathrm{Ca}^{2+}$. GLP-1 sensitizes intracellular $\mathrm{Ca}^{2+}$ release channels (ryanodine and $\mathrm{IP}_{3}$ receptors) to stimulatory effects of $\mathrm{Ca}^{2+}$, thereby promoting $\mathrm{Ca}^{2+}$-induced $\mathrm{Ca}^{2+}$ release (CICR). In the model presented here, CICR activates mitochondrial dehydrogenases, thereby upregulating glucose-dependent production of ATP. The resultant increase in cytosolic [ATP]/[ADP] concentration ratio leads to closure of ATP-sensitive $\mathrm{K}^{+}$channels (K-ATP), membrane depolarization, and influx of $\mathrm{Ca}^{2+}$ through voltage-dependent $\mathrm{Ca}^{2+}$ channels (VDCCs) $\mathrm{Ca}^{2+}$ influx stimulates exocytosis of secretory granules by promoting their fusion with the plasma membrane. Under conditions where $\mathrm{Ca}^{2+}$ release channels are sensitized by GLP-1, $\mathrm{Ca}^{2+}$ influx also stimulates CICR, generating an additional round of ATP production and K-ATP channel closure. In the absence of glucose, no "fuel" is available to support ATP production, and GLP-1 fails to stimulate insulin secretion. This new "feed-forward" hypothesis of $\beta$-cell stimulussecretion coupling may provide a mechanistic explanation as to how GLP-1 exerts a beneficial blood glucose-lowering effect in type 2 diabetic subjects.
\end{abstract}

\section{Keywords}

Glucose; GLP-1; cAMP; PKA; Epac; Insulin secretion

\section{Introduction}

Glucagon-like peptide-1-(7-36)-amide (GLP-1) is a blood glucose-lowering hormone that activates a surprisingly diverse array of signaling pathways in the pancreatic $\beta$-cell. Binding of GLP-1 to its $62 \mathrm{kDa}$ Class B heptahelical $\mathrm{G}_{\mathrm{S}}$-protein-coupled receptor activates adenylyl cyclase, stimulates cAMP production, and potentiates glucose-dependent insulin secretion from the pancreas [1,2]. First-phase and second-phase insulin secretion are enhanced, and pulsatile insulin secretion in humans is augmented [3,4]. These immediate effects of GLP-1

(C) Georg Thieme Verlag KG Stuttgart · New York

Correspondence G. G. Holz, Ph.D., Associate Professor, Department of Physiology and Neuroscience, Medical Sciences Building Room 442, 550 First Avenue, New York University School of Medicine, New York, NY 10016, U.S.A., Phone: +1 (212) 2635434, Fax: +1 (212) 68990 60, holzg01@ popmail.med.nyu.edu. 
are complemented by its delayed insulinotropic action in stimulating insulin gene transcription and upregulating translational biosynthesis of preproinsulin $[5,6]$. By serving as an intermediary linking intestinal nutrient absorption to pancreatic insulin secretion, GLP-1 fulfills its physiological role as an incretin hormone within the enteroinsular axis $[7,8]$.

Simultaneously, GLP-1 increases pancreatic insulin secretory capacity by stimulating the formation of new $\beta$-cells within the islets of Langerhans. Activation of GLP-1 receptors accelerates the conversion of pancreatic ductal stem cells to new $\beta$-cells while exerting a major proliferative effect in stimulating mitosis in existing $\beta$-cells $[9,10]$. These neogenic and proliferative actions of GLP- 1 are complemented by its ability to protect against $\beta$-cell death [11-14]. It may be concluded that in addition to its insulinotropic properties, GLP-1 acts as a $\beta$-cell growth factor.

Growth factor-like actions of GLP-1 result from its ability to stimulate mitogen-activated protein kinases (p38 MAPK, ERK1/2), src kinase (pp60 $0^{\mathrm{src}}$ ), phosphatidylinositol 3-kinase (PI-3K), atypical protein kinase $\mathrm{C}-\zeta$ (PKC- $\zeta)$, and protein kinase B (PKB, Akt) $[15,16]$. GLP-1 also transactivates the epidermal growth factor receptor (EGF-R) [16], upregulates the expression of insulin receptor substrate 2 (IRS-2) [17], and interacts with insulin or insulin-like growth factor 1 (IGF-1) signaling pathways that control $\beta$-cell function [18]. By influencing the function of key transcription factors (CREB; PDX-1), GLP-1 stimulates coordinate gene expression, thereby maintaining $\beta$-cells in a fully differentiated state [1921].

This constellation of unique insulinotropic and growth factor-like signaling properties has prompted interest in the use of GLP-1 and its synthetic peptide analogs (Exenatide, NN2211, CJC-1131) as novel blood glucose lowering agents for treatment of type 2 diabetes mellitus [22]. When administered to type 2 diabetic subjects, GLP-1 lowers the concentration of fasting blood glucose, restores the missing first phase component of glucose-dependent insulin secretion, and delays the postprandial hyperglycemic excursion. Since GLP-1 is rapidly degraded by dipeptidyl peptidase IV (DPP-IV), the antidiabetogenic properties of endogenously secreted GLP-1 are enhanced by DPP-IV inhibitors (LAF237, MK-0431, NN7201) [23].

Summarized here are new findings that shed light on how GLP-1 exerts its stimulatory effect on pancreatic insulin secretion. Presented is a new "feed-forward" hypothesis for stimulus-secretion coupling that seeks to explain how GLP-1 interacts with oxidative glucose metabolism to regulate mitochondrial ATP production, ion channel function, $\mathrm{Ca}^{2+}$ signaling, and exocytosis in the $\beta$-cell. For additional discussion of GLP- 1 and the $\beta$-cell signaling pathways it regulates, the reader is referred to a prior review of this subject matter [24].

\section{GLP-1 as an Insulin Secretagogue Hormone}

It is now established that the insulin secretagogue action of GLP-1 is dependent on exposure of $\beta$-cells to concentrations of glucose that are themselves stimulatory for insulin secretion. This interaction is understandable if GLP- 1 acts as a modulator of the $\beta$-cell glucose signaling system. Prior studies have demonstrated that GLP-1 increases the efficacy (maximal effect) and potency (threshold concentration) of glucose as a stimulus for insulin secretion [25]. As GLP-1 fails to stimulate insulin secretion in the absence of glucose, the available evidence indicates that it acts as a $\beta$-cell "glucose sensitizer." This action may explain how GLP-1 restores glucose-dependent insulin secretion in metabolically compromised $\beta$-cells, a phenomenon referred to as the induction of "glucose competence" $[26,27]$. 
When administered to human subjects, GLP-1 only stimulates insulin secretion when the concentration of blood glucose is above fasting levels. Since the concentration of blood glucose falls in response to administered GLP-1, the insulin secretagogue action of GLP-1 is self-terminating. Therefore, unlike insulin, GLP-1 possesses a natural safeguard and is less likely to induce hypoglycemia.

To understand why the insulin secretagogue action of GLP-1 is glucose-dependent, it is first necessary to consider exactly how metabolism of glucose influences $\beta$-cell function (Fig. 1). The ability of $\beta$-cells to sense extracellular glucose requires uptake of the sugar via a type 2 facilitative glucose transporter (Glut2). Glucokinase, a type IV hexokinase that is ratelimiting for glucose sensing, converts glucose to glucose-6-phosphate, which is then metabolized via glycolysis to generate pyruvate. Oxidation of pyruvate by mitochondrial pyruvate dehydrogenase generates acetyl-CoA which is utilized in the Krebs cycle to generate hydrogen atoms for respiratory chain electron transport, oxidative phosphorylation, and synthesis of ATP. The ensuing increase in cytosolic [ATP]/[ADP] concentration ratio inhibits efflux of $\mathrm{K}^{+}$through plasma membrane ATP-sensitive $\mathrm{K}^{+}$channels (K-ATP). The resulting membrane depolarization activates voltage-dependent $\mathrm{Ca}^{2+}$ channels (VDCCs), thereby stimulating $\mathrm{Ca}^{2+}$ influx, an increase in $\left[\mathrm{Ca}^{2+}\right]_{i}$, and exocytosis of secretory granules.

This sequence of metabolic and ionic events constitutes a "triggering" pathway for insulin secretion (Fig. 1) [28]. What is remarkable is that GLP-1 acts as a modulator of this triggering pathway. GLP-1 interacts with glucose metabolism to promote mitochondrial ATP production [29], thereby increasing the cytosolic [ATP]/[ADP] concentration ratio. GLP-1 also modifies the adenine nucleototide-sensitivity of K-ATP channels, reducing their sensitivity to ADP while increasing their sensitivity to ATP [30,31]. The net effect is glucose-dependent K-ATP channel closure, membrane depolarization and $\mathrm{Ca}^{2+}$ influx.

The importance of K-ATP channels as targets of GLP-1 action has been emphasized by recent reports demonstrating that the insulin secretagogue action of GLP-1 is diminished in sulfonylurea receptor 1 (SUR1) "knock out" (KO) mice that lack K-ATP channels $[32,33]$. SUR1 is a subunit of the K-ATP channel, and it mediates inhibitory effects of GLP-1 and glucose metabolism on channel function. An alternative interpretation of this KO phenotype is that SUR1 may also regulate the ATP-dependent priming of secretory granules, a step that renders them release competent [34]. Since SUR1 KO mice have a reduced number of primed granules available for exocytosis, this alternative interpretation predicts that these mice should exhibit a generalized secretory defect not necessarily related to the inhibition of K-ATP channels. However, the finding that $\beta$-cells derived from SUR1 KO exhibit a robust secretory response to administered acetylcholine runs against this alternative interpretation $[33,35]$.

There is also an "amplification" pathway for glucose-dependent insulin secretion (Fig. 1) [28]. The amplification pathway increases the effectiveness of $\mathrm{Ca}^{2+}$ as a stimulus for exocytosis, and may also be responsible for the recruitment of secretory granules to the plasma membrane. Because the amplification pathway stimulates exocytosis in a $\mathrm{Ca}^{2+}$ dependent manner, this mechanism requires an increase in $\left[\mathrm{Ca}^{2+}\right]_{i}$ generated by the triggering pathway. For this reason, outdated terminology equating amplification to a " $\mathrm{K}$ ATP-independent" mechanism of exocytosis should be abandoned. Instead, available evidence indicates that the amplification pathway facilitates exocytosis stimulated by the triggering pathway.

An explanation for how GLP-1 might upregulate the function of the amplification pathway is provided by the "malonyl Co-A hypothesis" of glucose-dependent insulin secretion [36]. Carboxylation of pyruvate by pyruvate carboxylase allows $\beta$-cell glucose metabolism to 
generate citrate that is exported out of the mitochondria for ultimate conversion to malonylCoA. Since malonyl-CoA inhibits mitochondrial oxidation of free fatty acids (FFAs), its synthesis links glucose metabolism to increased levels of cytosolic FFAs. Increased availability of FFAs favors the synthesis of long-chain fatty acyl-CoA esters (LC-CoA) and diacylglycerol (DAG). Both lipid metabolites are proposed to exert stimulatory effects on insulin secretion by virtue of their ability to promote acylation (LC-CoA) and protein kinase $\mathrm{C}$ mediated phosphorylation (DAG) of secretory granule-associated proteins. The net effect is an "amplification" of $\mathrm{Ca}^{2+}$-dependent exocytosis. Since GLP-1 acts via PKA to stimulate lipolysis and to liberate FFAs [37], it may also stimulate glucose-dependent production of LC-CoA and/or DAG, thereby favoring amplification.

\section{PKA and Epac-mediated Signaling Properties of the GLP-1 Receptor}

Although GLP-1 activates multiple signaling pathways in the $\beta$-cell, all available evidence indicates that the second messenger, cAMP, serves as the primary effector by which GLP-1 exerts its insulin secretagogue action [24]. New findings demonstrate that GLP-1 utilizes cAMP to activate not only protein kinase A (PKA), but also the Epac family (Epac1, Epac2) of cAMP-regulated guanine nucleotide exchange factors (cAMPGEFs) [38]. cAMPGEFs are cAMP-binding proteins that couple cAMP production to the activation of low molecularweight G-proteins of the Rap family (Rap1, Rap2). Potential downstream effectors of the activated cAMPGEF/Rap signaling complex include ERK1/2 MAPK, phospholipase C-E, and PKB [38].

One PKA-mediated action of GLP-1 is to inhibit K-ATP channel function via phosphorylation of the channel's SUR1 subunit [30]. This action of GLP-1 upregulates the triggering pathway and may be of particular importance for the appearance of first-phase glucose-dependent insulin secretion in type 2 diabetic subjects. It is also apparent that GLP-1 utilizes PKA to recruit secretory granules from a reserve pool to a readily releasable pool [34,39]. This action of GLP-1 supports sustained exocytosis, and may allow for the appearance of second-phase insulin secretion in type 2 diabetic subjects. The PKA-mediated recruitment of secretory granules is complemented by a "post priming" action of PKA to facilitate $\mathrm{Ca}^{2+}$-dependent fusion of secretory granules with the plasma membrane [40]. This action of PKA may upregulate the triggering and amplification pathways simultaneously.

Actions of GLP-1 mediated by cAMPGEFs include its ability to stimulate ATP-dependent priming of secretory granules, thereby rendering them release-competent [34]. This action of GLP-1 may result from interactions of Epac2 with insulin granule-associated proteins (Rim2, Piccolo) [41,42] or with SUR1 [43]. Since direct protein-protein interactions of Epac2 and SUR1 are demonstrable [43], it seems likely that cAMPGEFs may also confer cAMP-dependent inhibition of K-ATP channel activity, possibly by increasing the channel's sensitivity to ATP [31]. In summary, some actions of GLP-1 are Epac-mediated and may be independent of Rap G-proteins.

\section{GLP-1 Stimulates $\mathrm{Ca}^{2+}$ Influx and Mobilizes an Intracellular Source of $\mathrm{Ca}^{2+}$}

GLP-1 exerts pronounced stimulatory effects on $\beta$-cell $\mathrm{Ca}^{2+}$ signaling [44-46], actions that underlie its ability to promote $\mathrm{Ca}^{2+}$-dependent exocytosis of secretory granules. Exposure of $\beta$-cells to GLP-1 stimulates a fast transient increase in $\left[\mathrm{Ca}^{2+}\right]_{\mathrm{i}}$ followed by a slowly developing and sustained increase [47]. The transient increase in $\left[\mathrm{Ca}^{2+}\right]_{\mathrm{i}}$ results from cAMP-dependent release of $\mathrm{Ca}^{2+}$ from intracellular $\mathrm{Ca}^{2+}$ stores [47,48], whereas the sustained increase results from influx of $\mathrm{Ca}^{2+}$ through VDCCs [44]. These effects of GLP-1 require $\beta$-cell glucose metabolism and result from simultaneous activation of PKA [44] and Epac [49]. 
Although GLP-1 exerts a small direct stimulatory action at VDCCs [39], the primary impetus for $\mathrm{Ca}^{2+}$ influx through these channels is the membrane depolarization that results from interactions of GLP-1 and glucose metabolism to inhibit K-ATP channel function (Fig. 1). This action of GLP-1 is complemented by its ability to inhibit $\mathrm{K}^{+}$efflux through voltagedependent delayed rectifier $\mathrm{K}^{+}$channels $\left(\mathrm{K}_{\mathrm{V}}\right)$, thereby slowing action potential repolarization (Fig. 1). Inhibition of $\mathrm{K}_{\mathrm{V}}$ channels by GLP-1 requires not only PKA-mediated phosphorylation, but also EGF-R transactivation with concomitant stimulation of PI-3K and PKC- $\zeta[50]$.

The mobilization of intracellular $\mathrm{Ca}^{2+}$ by GLP-1 is a process of $\mathrm{Ca}^{2+}$-induced $\mathrm{Ca}^{2+}$ release (CICR), and is initiated by the increase in $\left[\mathrm{Ca}^{2+}\right]_{\mathrm{i}}$ that results from $\mathrm{Ca}^{2+}$ influx through VDCCs (Fig. 2). GLP-1 most likely acts via PKA and Epac to sensitize ryanodine receptor (RYR) and $\mathrm{IP}_{3}$ receptor $\left(\mathrm{IP}_{3}-\mathrm{R}\right)$ intracellular $\mathrm{Ca}^{2+}$ release channels to stimulatory effects of $\mathrm{Ca}^{2+}$, thereby gating the channels from a closed to open conformation [48,49,51-53]. A novel form of second messenger coincidence detection may exist in which a simultaneous increase in intracellular cAMP and $\mathrm{Ca}^{2+}$ concentrations allows for the appearance of CICR (Fig. 2).

Interestingly, the source of $\mathrm{Ca}^{2+}$ mobilized via CICR may reside not only in the endoplasmic reticulum (ER) [47,49], but also within the secretory granules (SG) [54]. Because RYR is expressed on the ER and SG membranes [55], CICR is expected to release $\mathrm{Ca}^{2+}$ from both cellular compartments (Fig. 2). What remains to be determined is exactly how GLP-1 modifies the function of $\mathrm{Ca}^{2+}$ release channels. Precedent exists for stimulatory actions of cAMP at RYR and $\mathrm{IP}_{3}-\mathrm{R} \mathrm{Ca}^{2+}$ release channels, actions attributable to PKAmediated phosphorylation $[47,48,52,53]$. Such an effect might be complemented by Epacmediated actions of cAMP, either through direct interactions of Epac with the channels, or via PKA-independent phosphorylation of the channels [49,51].

Although $\mathrm{Ca}^{2+}$ influx through VDCCs is established to be a stimulus for insulin secretion, is also clear that exocytosis results from the release of $\mathrm{Ca}^{2+}$ from intracellular $\mathrm{Ca}^{2+}$ stores [56]. $\mathrm{Ca}^{2+}$ influx stimulates CICR when $\beta$-cells are exposed to glucose in the presence of GLP-1. Under these conditions, CICR generates a global increase in $\left[\mathrm{Ca}^{2+}\right]_{\mathrm{i}}$ that stimulates the exocytosis of a large number of secretory granules located at a considerable distance from VDCCs (Fig. 3). In the absence of GLP-1, glucose-dependent $\mathrm{Ca}^{2+}$ influx fails to stimulate CICR, so only a small number of secretory granules are released at "active zones" where the opening of VDCCs generates microdomains of elevated $\left[\mathrm{Ca}^{2+}\right]_{\mathrm{i}}$. These observations indicate that the spatial distribution of intracellular $\mathrm{Ca}^{2+}$ dictates the pattern of exocytosis observed during the feeding and fasting states (Fig. 3) [56].

\section{GLP-1 Stimulates Mitochondrial ATP Production}

Whereas the insulin secretagogue action of GLP-1 is blocked by mannoheptulose [57], a glycolysis inhibitor, it is supported by succinic acid dimethyl ester [58], a non-glucidic nutrient that becomes available for mitochondrial metabolism once deesterified. It may be concluded that events intimately associated with glycolytic and mitochondrial metabolism are necessary prerequisites for an effective $\beta$-cell secretory response to GLP-1. Confirmation that this is the case has been provided by new studies examining the stimulatory effect of GLP-1 on mitochondrial ATP concentration ([ATP $]_{\mathrm{m}}$ ). These studies reveal a previously unrecognized ability of GLP-1 to increase [ATP $]_{m}$ in MIN6 insulin-secreting cells [29]. This action of GLP-1 requires exposure of cells to glucose, as expected if GLP-1 stimulates glucose-dependent mitochondrial ATP production. The stimulatory effect of GLP-1 on $[\mathrm{ATP}]_{\mathrm{m}}$ is accompanied by CICR, and is not observed when intracellular $\mathrm{Ca}^{2+}$ is buffered or when $\mathrm{Ca}^{2+}$ stores are depleted [29]. 
These findings are of interest from the perspective of current concepts regarding "metabolic priming" in the $\beta$-cell. Metabolic priming is a facilitation of mitochondrial ATP production, and it is observed under experimental conditions that produce an increase in $\left[\mathrm{Ca}^{2+}\right]_{i}[59]$. When $\beta$-cells are equilibrated in a low concentration of glucose, brief application of $\mathrm{KCl}$ produces $\mathrm{Ca}^{2+}$ influx, an increase in $\left[\mathrm{Ca}^{2+}\right]_{\mathrm{i}}$, and a slight increase in $[\mathrm{ATP}]_{\mathrm{m}} . \mathrm{KCl}$ "preconditioning" of this type produces metabolic priming since it allows for a larger increase in $[\mathrm{ATP}]_{\mathrm{m}}$ than normal when $\beta$-cells are subsequently exposed to a higher concentration of glucose [60]. These observations suggest that, as with $\mathrm{KCl}$, GLP-1 might act via $\mathrm{Ca}^{2+}$ to prime a key step of mitochondrial metabolism important in glucosedependent ATP production. Indeed, a stimulation of Krebs cycle and/or NADH shuttlelinked mitochondrial dehydrogenases by $\mathrm{Ca}^{2+}$ might explain how a $\mathrm{Ca}^{2+}$-elevating hormone such as GLP-1 interacts with $\beta$-cell glucose metabolism to stimulate ATP production [61].

\section{GLP-1 Inhibits K-ATP Channel Function}

$\mathrm{K}$-ATP channel activity in $\beta$-cells is reduced under conditions that produce a simultaneous increase in intracellular cAMP and $\mathrm{Ca}^{2+}$ concentrations [62]. Inhibition of K-ATP channels by cAMP-elevating agents is associated with increased levels of reduced pyridine nucleotides, as measured by the determination of $\mathrm{NAD}(\mathrm{P}) \mathrm{H}$ autofluorescence [63]. Reduced pyridine nucleotides accumulate as a consequence of oxidative glucose metabolism, suggesting a previously unrecognized interaction of cAMP and $\mathrm{Ca}^{2+}$ to stimulate mitochondrial ATP production and to increase the cytosolic [ATP]/[ADP] concentration ratio while inhibiting K-ATP channel function. Taken together, such findings provide additional evidence for the existence of a novel form of second messenger coincidence detection critical to $\beta$-cell function. By mobilizing $\mathrm{Ca}^{2+}$ stores in a cAMP and $\mathrm{Ca}^{2+}$ dependent manner, GLP-1 may generate a cytosolic $\mathrm{Ca}^{2+}$ signal (CICR) that is a stimulus for glucose-dependent ATP production and K-ATP channel inhibition.

Stimulatory effects of GLP-1 on mitochondrial ATP production are accompanied by alterations in K-ATP channel adenine nucleotide sensitivity. GLP-1 decreases the channel's sensitivity to ADP, thereby inhibiting channel function [30]. This action of GLP-1 is cAMPdependent and is mediated by PKA. In contrast, GLP-1 acts independently of PKA to increase the channel's sensitivity to ATP, thereby closing the channel [31]. Although not yet confirmed, this PKA-independent action of GLP-1 might reflect its ability to activate Epac [38]. Such alterations of adenine nucleotide sensitivity are likely to play a major role in determining the effectiveness of mitochondrial ATP production as an inhibitor of K-ATP channel function. For example, $\mathrm{Ca}^{2+}$-mobilizing transmitters that fail to stimulate cAMP production may also fail to influence K-ATP channel adenine nucleotide sensitivity; under these conditions, their stimulatory effect on mitochondrial ATP production may not be accompanied by a detectable decrease in K-ATP channel activity.

\section{Conclusion: A "Feed-forward Hypothesis" for Regulated Insulin Secretion}

Fig. 4 shows a model that seeks to explain how GLP-1 interacts with $\beta$-cell glucose metabolism to stimulate insulin secretion. The model predicts that metabolic priming within mitochondria plays a key role in allowing GLP-1 to upregulate glucose-dependent ATP production. Under conditions where intracellular $\mathrm{Ca}^{2+}$ release channels are sensitized by GLP-1, $\mathrm{Ca}^{2+}$ influx triggers CICR, generating a $\mathrm{Ca}^{2+}$ signal that stimulates the activity of mitochondrial dehydrogenases. This increases $[\mathrm{ATP}]_{\mathrm{m}}$ and increases the cytosolic $[\mathrm{ATP}] /$ [ADP] concentration ratio. K-ATP channels close, the membrane is depolarized, and VDCCs are activated. $\mathrm{Ca}^{2+}$ influx through VDCCs stimulates exocytosis, while stimulating another round of CICR and ATP production. This sequence of events constitutes a selfperpetuating "feed-forward" mechanism that is responsible for the glucose-dependent 
closure of K-ATP channels. Note that this action of GLP-1 is complemented by its ability to modulate the adenine nucleotide-sensitivity of K-ATP channels, thereby favoring their closure. Also note that the ability of GLP-1 to activate this feed-forward mechanism is dependent on the presence of glucose since glucose serves as the "fuel" for mitochondrial ATP production. This model agrees with the known ability of cAMP-elevating agents to inhibit single K-ATP channel activity, reduce the membrane conductance, and depolarize $\beta$ cells $[27,64,65]$. The model may also explain earlier reports that activators of cAMP signaling depolarize the silent phase of glucose-induced "bursts" of action potentials in intact islets [66-68]. Depolarization of this type augments oscillatory electrical activity that drives $\mathrm{Ca}^{2+}$ influx and which initiates pulsatile secretion of insulin.

\section{Acknowledgments}

G. G. H. acknowledges the contributions of Drs. G. Kang and O. G. Chepurny to the research program. Support for these studies is provided by the National Institutes of Health (R01-DK45817), the American Diabetes Association (Research Grant Award), and the Marine Biological Laboratory, Woods Hole, MA (Summer Research Fellowship).

\section{References}

1. Mojsov S, Weir GC, Habener JF. Insulinotropin: glucagon-like peptide-1-(7-37) co-encoded in the glucagon gene is a potent stimulator of insulin release in the perfused rat pancreas. J Clin Invest 1987;79:616-619. [PubMed: 3543057]

2. Thorens B. Expression cloning of the pancreatic $\beta$-cell receptor for the gluco-incretin hormone glucagon-like peptide-1. Proc Natl Acad Sci (USA) 1992;89:8641-8645. [PubMed: 1326760]

3. Nathan DM, Schreiber E, Mojsov S, Habener JF. Insulinotropic action of glucagon-like peptide-1(7-37) in diabetic and nondiabetic subjects. Diabetes Care 1992;15:270-276. [PubMed: 1547685]

4. Gutniak MK, Orskov C, Holst JJ, Ahren B, Efendic S. Antidiabetogenic effect of glucagon-like peptide-1-(7-36)-amide in normal subjects and patients with diabetes mellitus. N Eng J Med 1992;326:1316-1322.

5. Drucker DJ, Philippe H, Mojsov S, Chick WL, Habener JF. Glucagon-like peptide-1 stimulates insulin gene expression and increases cyclic AMP levels in a rat islet cell line. Proc Natl Acad Sci (USA) 1987;84:3434-3438. [PubMed: 3033647]

6. Fehmann HC, Habener JF. Insulinotropic hormone glucagon-like peptide-1-(7-37) stimulation of proinsulin gene expression and proinsulin biosynthesis in insulinoma $\beta \mathrm{TC}-1$ cells. Endocrinology 1992;130:159-166. [PubMed: 1309325]

7. Kreymann B, Ghatei MA, Williams G, Bloom SR. Glucagon-like peptide-1-(7-36): A physiological incretin in man. Lancet 1987;2:300-1304.

8. Holst JJ. Glucagon-like peptide-1: A newly discovered gastrointestinal hormone. Gastroenterology 1994;107:848-1855.

9. Xu G, Stoffers DA, Habener JF, Bonner-Weir S. Exendin-4 stimulates both $\beta$-cell replication and neogenesis, resulting in increased $\beta$-cell mass and improved glucose tolerance in diabetic rats. Diabetes 1999;48:2270-2276. [PubMed: 10580413]

10. Stoffers DA, Kieffer TJ, Hussain MA, Drucker DJ, Bonner-Weir S, Habener JF, Egan JM. Insulinotropic glucagon-like peptide-1 agonists stimulate expression of homeodomain protein IDX-1 and increase islet size in mouse pancreas. Diabetes 2000;49:741-748. [PubMed: 10905482]

11. Farilla L, Bulotta A, Hirshberg B, Li Calzi S, Khoury N, Noushmehr H, Bertolotto C, Di Mario U, Harlan DM, Perfetti R. Glucagon-like peptide-1 inhibits cell apoptosis and improves glucose responsiveness of freshly isolated human islets. Endocrinology 2003;144:5149-5158. [PubMed: 12960095]

12. Li Y, Hansotia T, Yusta B, Ris F, Halban PA, Drucker DJ. Glucagon-like peptide-1 receptor signaling modulates $\beta$-cell apoptosis. J Biol Chem 2003;278:471-478. [PubMed: 12409292]

13. Wang Q, Li L, Xu E, Wong V, Rhodes C, Brubaker PL. Glucagon-like peptide-1 regulates proliferation and apoptosis via activation of protein kinase B in pancreatic INS-1 $\beta$-cells. Diabetologia 2004;47:478-487. [PubMed: 14762654] 
14. Buteau J, El-Assaad W, Rhodes CJ, Rosenberg L, Joly E, Prentki M. Glucagon-like peptide-1 prevents $\beta$-cell glucolipotoxicity. Diabetologia 2004;47:806-815. [PubMed: 15095038]

15. Buteau J, Foisy S, Rhodes CJ, Carpenter L, Biden TJ, Prentki M. Protein kinase C- $\zeta$ activation mediates glucagon-like peptide-1-induced pancreatic $\beta$-cell proliferation. Diabetes 2001;50:22372243. [PubMed: 11574404]

16. Buteau J, Foisy S, Joly E, Prentki M. Glucagon-like peptide-1 induces pancreatic $\beta$-cell proliferation via transactivation of the epidermal growth factor receptor. Diabetes 2003;52:124132. [PubMed: 12502502]

17. Jhala US, Canettieri G, Screaton RA, Kulkarni RN, Krajewski S, Reed J, Walker J, Lin X, White M, Montminy M. cAMP promotes pancreatic $\beta$-cell survival via CREB-mediated induction of IRS2. Genes Dev 2003;17:1575-1580. [PubMed: 12842910]

18. Trumper K, Trumper A, Trusheim H, Arnold R, Goke B, Horsch D. Integrative mitogenic role of protein kinase B/Akt in $\beta$-cells. Ann N Y Acad Sci 2000;921:242-250. [PubMed: 11193829]

19. Dalle S, Longuet C, Costes S, Broca C, Faruque O, Fontes G, Hani el H, Bataille D. Glucagon promotes cAMP-response element-binding protein phosphorylation via activation of ERK1/2 in MIN6 cell line and isolated islets of Langerhans. J Biol Chem 2004;279:20345-20355. [PubMed: 14988413]

20. Buteau J, Roduit R, Susini S, Prentki M. Glucagon-like peptide-1 promotes DNA synthesis, activates phosphatidylinositol 3-kinase and increases transcription factor pancreatic and duodenal homeobox gene 1 (PDX-1) DNA binding activity in beta (INS-1) -cells. Diabetologia 1999;42:856-864. [PubMed: 10440129]

21. Wang X, Zhou J, Doyle ME, Egan JM. Glucagon-like peptide-1 causes pancreatic duodenal homeobox-1 protein translocation from the cytoplasm to the nucleus of pancreatic $\beta$-cells by a cyclic adenosine monophosphate/protein kinase-A-dependent mechanism. Endocrinology 2001;142:1820-1827. [PubMed: 11316746]

22. Holz GG, Chepurny OG. Glucagon-like peptide-1 synthetic analogs: new therapeutic agents for use in the treatment of diabetes mellitus. Curr Med Chem 2003;10:2471-2483. [PubMed: 14529486]

23. Ahren B, Landin-Olsson M, Jansson PA, Svensson M, Holmes D, Schweizer A. Inhibition of dipeptidyl peptidase-4 reduces glycemia, sustains insulin levels, and reduces glucagon levels in type 2 diabetes. J Clin Endocrinol Metab 2004;89:2078-2084. [PubMed: 15126524]

24. Gromada J, Holst JJ, Rorsman P. Cellular regulation of islet hormone secretion by the incretin hormone glucagon-like peptide-1. Pflugers Arch 1998;435:583-594. [PubMed: 9479010]

25. Fridolf T, Ahren B. GLP-1(7-36)-amide stimulates insulin secretion in rat islets: studies on the mode of action. Diabetes Res 1991;16:185-191. [PubMed: 1802486]

26. Holz GG, Habener JF. Signal Transduction Crosstalk in the Endocrine System: Pancreatic $\beta$-Cells and the Glucose Competence Concept. Trends In Biochemical Sciences 1992;17:388-393. [PubMed: 1455507]

27. Holz GG, Kuhtreiber WM, Habener JF. Pancreatic $\beta$-cells are rendered glucose competent by the insulinotropic hormone glucagon-like peptide-1-(7-37). Nature 1993;361:362-365. [PubMed: 8381211]

28. Henquin JC. Triggering and amplifying pathways of regulation of insulin secretion by glucose. Diabetes 2000;49:1751-1760. [PubMed: 11078440]

29. Tsuboi T, da Silva Xavier, Holz GG, Jouaville LS, Thomas AP, Rutter GA. Glucagon-like peptide-1 mobilizes intracellular $\mathrm{Ca}^{2+}$ and stimulates mitochondrial ATP synthesis in pancreatic MIN6 $\beta$-cells. Biochem J 2003;369:287-299. [PubMed: 12410638]

30. Light PE, Manning F, Fox JE, Riedel MJ, Wheeler MB. Glucagon-like peptide-1 inhibits pancreatic ATP-sensitive potassium channels via a PKA- and ADP-dependent mechanism. Mol Endocrinol 2002;16:2135-2144. [PubMed: 12198249]

31. Suga S, Kanno T, Ogawa Y, Takeo T, Kamimura N, Wakui M. cAMP-independent decrease of ATP-sensitive $\mathrm{K}^{+}$channel activity by GLP-1 in rat pancreatic $\beta$-cells. Pflugers Arch 2000;440:566-572. [PubMed: 10958340] 
32. Nakazaki M, Crane A, Hu M, Seghers V, Ullrich S, Aguilar-Bryan L, Bryan J. cAMP-activated protein kinase-independent potentiation of insulin secretion by cAMP is impaired in SUR1 null islets. Diabetes 2002;51:3440-3449. [PubMed: 12453898]

33. Shiota C, Larsson O, Shelton KD, Shiota M, Efanov AM, Hoy M, Lindner J, Kooptiwut S, JunttiBerggren L, Gromada J, Berggren PO, Magnuson MA. Sulfonylurea receptor type 1 knock-out mice have intact feeding stimulated insulin secretion despite marked impairment in their response to glucose. J Biol Chem 2002;277:37176-37183. [PubMed: 12149271]

34. Eliasson L, Ma X, Renstrom E, Barg S, Berggren PO, Galvanovskis J, Gromada J, Jing X, Lundquist I, Salehi A, Sewing S, Rorsman P. SUR1 Regulates PKA-independent cAMP-induced granule priming in mouse pancreatic $\beta$-cells. J Gen Physiol 2003;121:181-197. [PubMed: 12601083]

35. Doliba NM, Qin W, Vatamaniuk MZ, Li C, Zelent D, Najafi H, Buettger CW, Collins HW, Carr RD, Magnuson MA, Matschinsky FM. Restitution of defective glucose-stimulated insulin release of sulfonylurea type 1 receptor knockout mice by acetylcholine. Am J Physiol Endocrinol Metab 2004;286:E834-E843. [PubMed: 14736703]

36. Prentki M, Corkey BE. Are the $\beta$-cell signaling molecules malonyl-CoA and cystolic long-chain acyl-CoA implicated in multiple tissue defects of obesity and NIDDM? Diabetes 1996;45:273283. [PubMed: 8593930]

37. Cunningham BA, Richard AM, Dillon JS, Daley JT, Civelek VN, Deeney JT, Yaney GC, Corkey BE, Tornheim K. Glucagon-like peptide-1 and fatty acids amplify pulsatile insulin secretion from perifused rat islets. Biochem J 2003;369:173-178. [PubMed: 12356335]

38. Holz GG. Epac: A new cAMP-binding protein in support of glucagon-like peptide-1 receptormediated signal transduction in the pancreatic $\beta$-cell. Diabetes 2004;53:5-13. [PubMed: 14693691]

39. Gromada J, Bokvist K, Ding WG, Holst JJ, Nielsen JH, Rorsman P. Glucagon-like peptide-1 (736)-amide stimulates exocytosis in human pancreatic $\beta$-cells by both proximal and distal regulatory steps in stimulus-secretion coupling. Diabetes 1998;47:57-65. [PubMed: 9421375]

40. Takahashi N, Kadowaki T, Yazaki Y, Ellis-Davies GCR, Miyashita Y, Kasai H. Post-priming actions of ATP on $\mathrm{Ca}^{2+}$-dependent exocytosis in pancreatic $\beta$-cells. Proc Natl Acad Sci (USA) 1999;96:760-765. [PubMed: 9892707]

41. Kashima Y, Miki T, Shibasaki T, Ozaki N, Miyazaki M, Yano H, Seino S. Critical role of cAMPGEFII Rim2 complex in incretin-potentiated insulin secretion. J Biol Chem 2001;276:4604646053. [PubMed: 11598134]

42. Fujimoto K, Shibasaki T, Yokoi N, Kashima Y, Matsumoto M, Sasaki T, Tajima N, Iwanaga T, Seino S. Piccolo, a $\mathrm{Ca}^{2+}$ sensor in pancreatic $\beta$-cells. Involvement of cAMP-GEFII.Rim2. Piccolo complex in cAMP-dependent exocytosis. J Biol Chem 2002;277:50497-50502. [PubMed: 12401793]

43. Shibasaki T, Sunaga Y, Fujimoto K, Kashima Y, Seino S. Interaction of ATP sensor, cAMP sensor, $\mathrm{Ca}^{2+}$ sensor, and voltage-dependent $\mathrm{Ca}^{2+}$ channel in insulin granule exocytosis. J Biol Chem 2004;279:7956-7961. [PubMed: 14660679]

44. Yada T, Itoh K, Nakata M. Glucagon-like peptide-1-(7-36)-amide and a rise in cyclic adenosine 3', 5 -monophosphate increase cytosolic free $\mathrm{Ca}^{2+}$ in rat pancreatic $\beta$-cells by enhancing $\mathrm{Ca}^{2+}$ channel activity. Endocrinology 1993;133:1685-1692. [PubMed: 8404610]

45. Bode HP, Moorman B, Dabew R, Goke B. Glucagon-like peptide-1 elevates cytosolic calcium in pancreatic $\beta$-cells independently of protein kinase A. Endocrinology 1999;140:3919-3927. [PubMed: 10465260]

46. Holz GG, Leech CA, Habener JF. Activation of a cAMP-regulated $\mathrm{Ca}^{2+}$-signalling pathway in pancreatic $\beta$-cells by the insulinotropic hormone glucagon-like peptide-1. J Biol Chem 1995;270:17749-17757. [PubMed: 7543091]

47. Holz GG, Leech CA, Heller RS, Castonguay M, Habener JF. cAMP-dependent mobilization of intracellular $\mathrm{Ca}^{2+}$ stores by activation of ryanodine receptors in pancreatic $\beta$-cells. J Biol Chem 1999;274:14147-14156. [PubMed: 10318832]

48. Gromada J, Dissing S, Bokvist K, Renstrom E, Frokjaer-Jensen J, Wulff BS, Rorsman P. Glucagon-like peptide-1 increases cytoplasmic calcium in insulin-secreting $\beta$ TC-3-cells by 
enhancement of intracellular calcium mobilization. Diabetes 1995;44:767-774. [PubMed: 7789644]

49. Kang G, Chepurny OG, Holz GG. cAMP-regulated guanine nucleotide exchange factor-II (Epac2) mediates $\mathrm{Ca}^{2+}$-induced $\mathrm{Ca}^{2+}$ release in INS-1 pancreatic ßeta-cells. J Physiol (Lond.) 2001;536:375-385. [PubMed: 11600673]

50. MacDonald PE, Wang X, Xia F, El-Kholy W, Targonsky ED, Tsushima RG, Wheeler MB. Antagonism of rat $\beta$-cell voltage-dependent $\mathrm{K}^{+}$currents by exendin- 4 requires dual activation of the cAMP/protein kinase A and phosphatidylinositol 3-kinase signaling pathways. J Biol Chem 2003;278:52446-52453. [PubMed: 14565957]

51. Kang G, Joseph JW, Chepurny OG, Monaco M, Wheeler MB, Bos JL, Schwede F, Genieser HG, Holz GG. Epac-selective cAMP analog 8-pCPT-2'-O-Me-cAMP as a stimulus for $\mathrm{Ca}^{2+}$-induced $\mathrm{Ca}^{2+}$ release and exocytosis in pancreatic $\beta$-cells. J Biol Chem 2003;278:8279-8285. [PubMed: 12496249]

52. Islam MS, Leibiger I, Leibiger B, Rossi D, Sorrentino V, Ekstrom TJ, Westerblad H, Andrade FH, Berggren PO. In situ activation of the type 2 ryanodine receptor in pancreatic $\beta$-cells requires cAMP-dependent phosphorylation. Proc Natl Acad Sci (USA) 1998;95:6145-6150. [PubMed: 9600932]

53. Liu YJ, Grapengiesser E, Gylfe E, Hellman B. Crosstalk between the cAMP and inositol trisphosphate-signalling pathways in pancreatic $\beta$-cells. Archiv Biochem Biophys 1996;334:295302.

54. Nakagaki I, Sasaki S, Hori S, Kondo H. $\mathrm{Ca}^{2+}$ and electrolyte mobilization following agonist application to the pancreatic $\beta$-cell line HIT. Pflugers Arch 2000;440:828-834. [PubMed: 11041547]

55. Mitchell KJ, Lai FA, Rutter GA. Ryanodine receptor type I and nicotinic acid adenine dinucleotide phosphate receptors mediate $\mathrm{Ca}^{2+}$ release from insulin-containing vesicles in living pancreatic $\beta$ cells (MIN6). J Biol Chem 2003;278:11057-11064. [PubMed: 12538591]

56. Kang G, Holz GG. Amplification of exocytosis by $\mathrm{Ca}^{2+}$-induced $\mathrm{Ca}^{2+}$ release in INS-1 pancreatic $\beta$-cells. J Physiol (Lond.) 2003;546:175-189. [PubMed: 12509487]

57. Zawalich WS, Zawalich KC, Rasmussen H. Influence of glucagon-like peptide-1 on $\beta$-cell responsiveness. Regul Pept 1992;44:277-283. [PubMed: 8484020]

58. Leclercq-Meyer V, Malaisse WJ. Potentiation of glucagon-like peptide-1 insulinotropic action by succinic acid dimethyl ester. Life Sciences 1996;58:1195-1199. [PubMed: 8614271]

59. Jouaville LS, Pinton P, Bastianutto C, Rutter GA, Rizzuto R. Regulation of mitochondrial ATP synthesis by $\mathrm{Ca}^{2+}$ : Evidence for a long-term metabolic priming. Proc Natl Acad Sci (USA) 1999;96:13807-13812. [PubMed: 10570154]

60. Ainscow EK, Rutter GA. Mitochondrial priming modifies $\mathrm{Ca}^{2+}$ oscillations and insulin secretion in pancreatic islets. Biochem J 2001;353:175-180. [PubMed: 11139378]

61. Rutter GA, Rizzuto R. Regulation of mitochondrial metabolism by ER $\mathrm{Ca}^{2+}$ release: an intimate connection. Trends Biochem Sci 2000;25:215-221. [PubMed: 10782088]

62. He LP, Mears D, Atwater I, Kitasato H. Glucagon induces suppression of ATP-sensitive $\mathrm{K}^{+}$ channel activity through a $\mathrm{Ca}^{2+} /$ calmodulin-dependent pathway in mouse pancreatic $\beta$-cells. $\mathrm{J}$ Membr Biol 1998;166:237-244. [PubMed: 9843597]

63. He LP, Kitasato H. Glucagon induces $\mathrm{Ca}^{2+}$-dependent increase of reduced pyridine nucleotides in mouse pancreatic $\beta$-cells. Biochim Biophys Acta 1996;131:325-323. [PubMed: 8599611]

64. Eddlestone GT, Oldham SB, Lipson LG, Premdas FH, Beigelman PM. Electrical activity, cAMP concentration, and insulin release in mouse islets of Langerhans. Am J Physiol 1985;248:C145C153. [PubMed: 2578253]

65. Barnett DW, Pressel DM, Chern HT, Scharp DW, Misler S. cAMP-enhancing agents "permit" stimulus secretion coupling in canine pancreatic islet $\beta$-cells. J Membrane Biol 1994;138:113-120. [PubMed: 7529322]

66. Henquin JC, Schmeer W, Meissner HP. Forskolin, an activator of adenylate cyclase, increases calcium-dependent electrical activity induced by glucose in mouse pancreatic $\beta$-cells. Endocrinology 1983;112:2218-2220. [PubMed: 6343063] 
67. Henquin JC, Meissner HP. The ionic, electrical, and secretory effects of endogenous cyclic adenosine monophosphate in mouse pancreatic $\beta$-cells: studies with forskolin. Endocrinology 1984;115:1125-1134. [PubMed: 6086286]

68. Ikeuchi M, Cook DL. Glucagon and forskolin have dual effects upon islet cell electrical activity. Life Sci 1984;35:685-691. [PubMed: 6087071] 


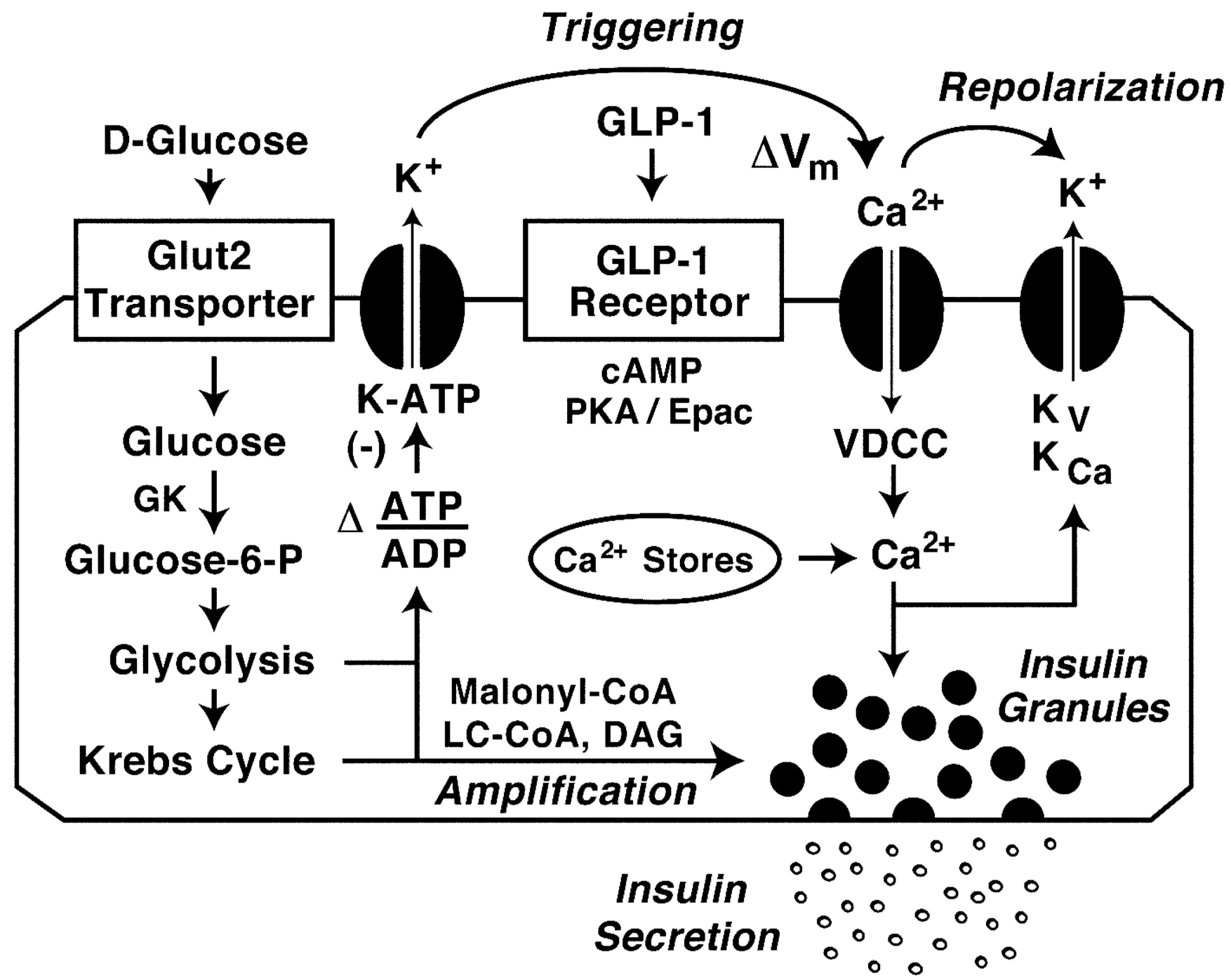

Fig. 1.

The "triggering" and "amplification" pathways by which oxidative glucose metabolism stimulates exocytosis. Uptake of glucose is mediated by the type 2 facilitative glucose transporter (Glut2), and glucose is converted to glucose-6-phosphate (glucose-6-P) by glucokinase (GK). Glycolytic and mitochondrial respiration produces an increase in [ATP]/ [ADP] concentration ratio that inhibits K-ATP channels. Membrane depolarization $\left(\Delta \mathrm{V}_{\mathrm{m}}\right)$, activates VDCCs, stimulates $\mathrm{Ca}^{2+}$ influx and initiates $\mathrm{Ca}^{2+}$-dependent exocytosis (triggering pathway). The opening of voltage-dependent $\mathrm{K}^{+}$channels $\left(\mathrm{K}_{\mathrm{V}}\right)$ and $\mathrm{Ca}^{2+}$-activated $\mathrm{K}^{+}$ channels $\left(\mathrm{K}_{\mathrm{Ca}}\right)$ terminates $\mathrm{Ca}^{2+}$ influx by repolarizing the membrane. Metabolism of glucose also generates coupling factors (malonyl CoA, LC-CoA, DAG) that facilitate $\mathrm{Ca}^{2+}$ dependent exocytosis (amplification pathway). GLP-1 potentiates glucose-dependent insulin secretion by virtue of its ability to stimulate cAMP production. The action of cAMP is mediated by PKA and Epac. 


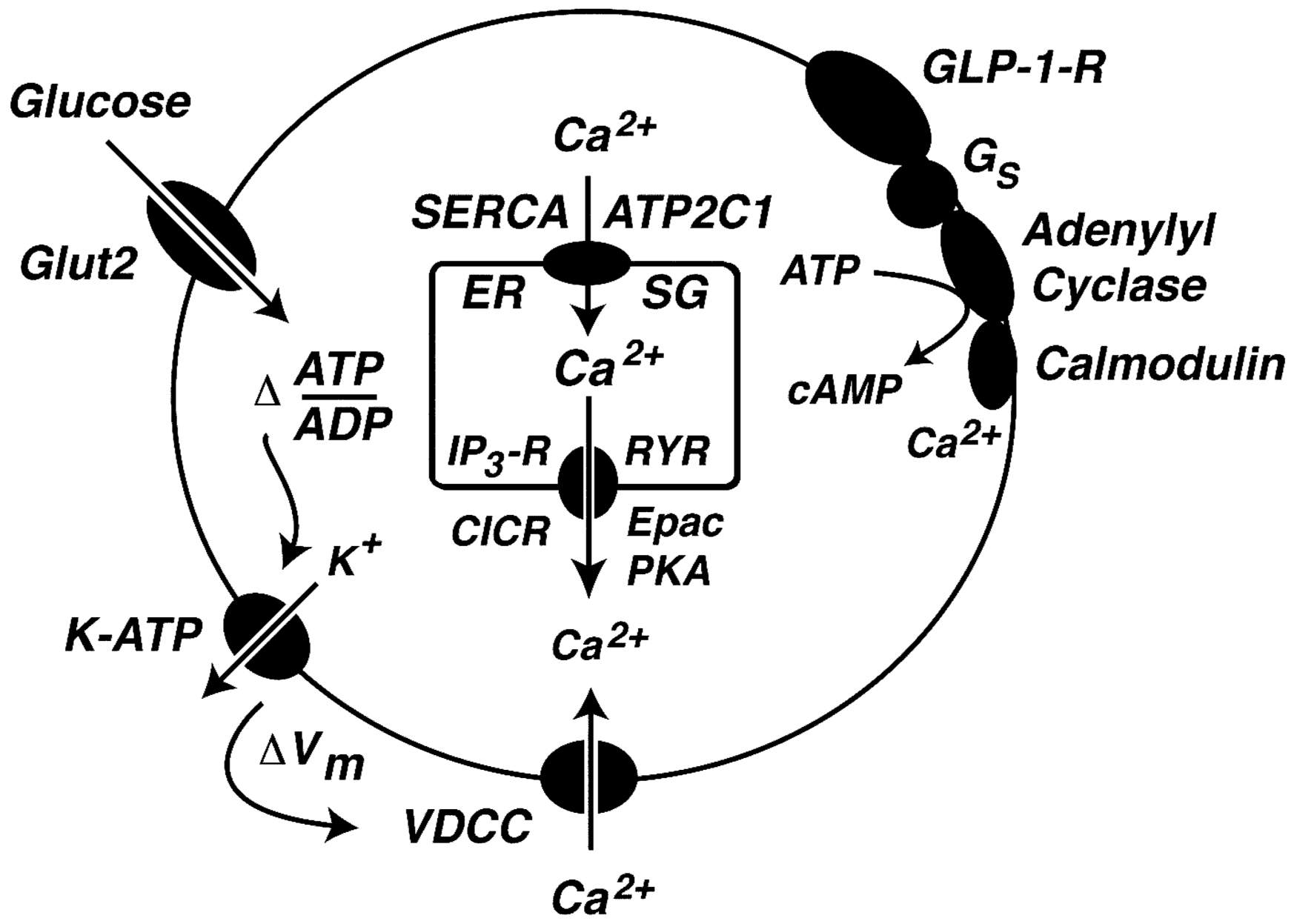

Fig. 2.

GLP-1 interacts with glucose metabolism to mobilize an intracellular source of $\mathrm{Ca}^{2+}$. Glucose-dependent closure of K-ATP channels produces membrane depolarization $\left(\Delta \mathrm{V}_{\mathrm{m}}\right)$ and influx of $\mathrm{Ca}^{2+}$ through VDCCs. GLP-1 sensitizes ryanodine receptor (RYR) and $\mathrm{IP}_{3}$ receptor $\left(\mathrm{IP}_{3}-\mathrm{R}\right)$ intracellular $\mathrm{Ca}^{2+}$ release channels to stimulatory effects of $\mathrm{Ca}^{2+}$, thereby allowing $\mathrm{Ca}^{2+}$ influx to initiate $\mathrm{Ca}^{2+}$-induced $\mathrm{Ca}^{2+}$ release (CICR) from $\mathrm{Ca}^{2+}$ stores located in the endoplasmic reticulum (ER) and secretory granules (SG). Uptake of $\mathrm{Ca}^{2+}$ into the ER and SG is mediated by the SERCA and ATP2C1 $\mathrm{Ca}^{2+}$-ATPases, respectively. RYR and IP $3^{-}$ $\mathrm{R} \mathrm{Ca}^{2+}$ release channels act as second messenger coincidence detectors because they open in response to a simultaneous increase in cAMP and $\mathrm{Ca}^{2+}$ concentrations. 


\section{Fasting State}

Region In Which

Exocytosis Occurs
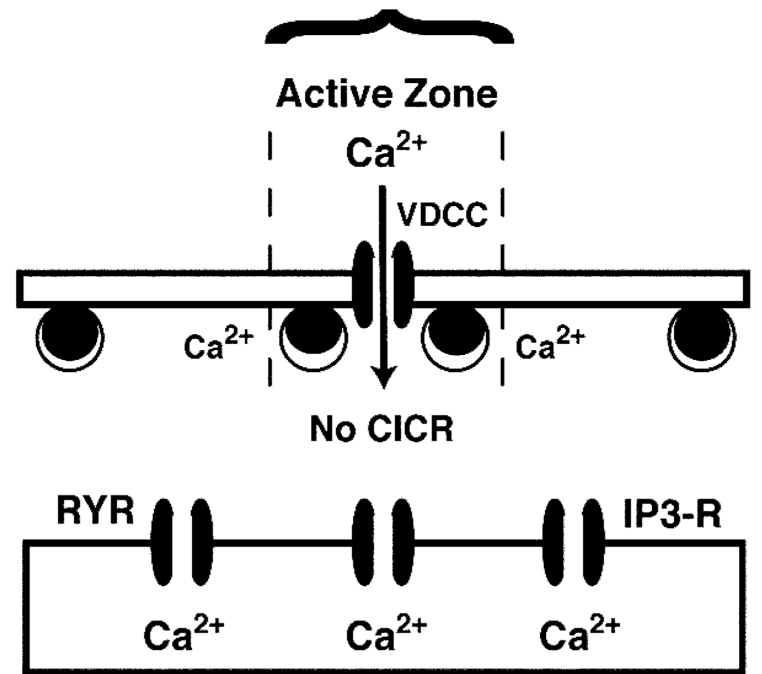

Low Blood [Glucose]

Low Blood [GLP-1]

Small Number Of Action Potentials No CICR

Exocytosis Of A Few Secretory Granules
Feeding State

Region In Which

Exocytosis Occurs

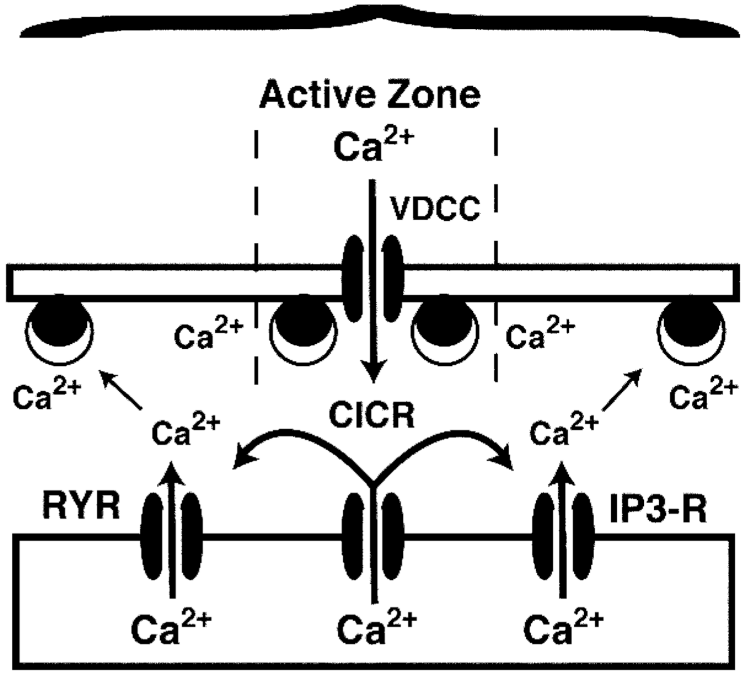

High Blood [Glucose]

High Blood [GLP-1]

Large Number Of Action Potentials

CICR Is Generated

Exocytosis Of Many Secretory Granules

Fig. 3.

Contrasting mechanisms of exocytosis that occur during the fasting and feeding states. In the fasting state, the concentration of blood glucose is low and $\beta$-cells generate action potentials infrequently. Exocytosis occurs at active zones where a small number of secretory granules are located in close proximity to VDCCs. Since the level of GLP-1 in the blood is not elevated during the fasting state, $\mathrm{RYR}$ and $\mathrm{IP}_{3}-\mathrm{R} \mathrm{Ca}^{2+}$ release channels are not sensitized, and no CICR is observed in response to $\mathrm{Ca}^{2+}$ influx. Under these conditions, the increase in $\left[\mathrm{Ca}^{2+}\right]_{\mathrm{i}}$ generated by influx of $\mathrm{Ca}^{2+}$ is spatially restricted and is unable to stimulate the release of secretory granules located outside of the active zones. Glucose and GLP-1 concentrations in the blood are elevated during the feeding state. Glucose and GLP-1 act synergistically to close K-ATP channels and to generate numerous action potentials. Simultaneously, GLP-1 sensitizes $\mathrm{Ca}^{2+}$ release channels to stimulatory effects of $\mathrm{Ca}^{2+}$, thus allowing the appearance of CICR in response to $\mathrm{Ca}^{2+}$ influx. CICR generates a global increase in $\left[\mathrm{Ca}^{2+}\right]$ and initiates the exocytosis of a large number of secretory granules located outside of the active zones. 


\section{"Feed-Forward Hypothesis" For Regulated Insulin Secretion}

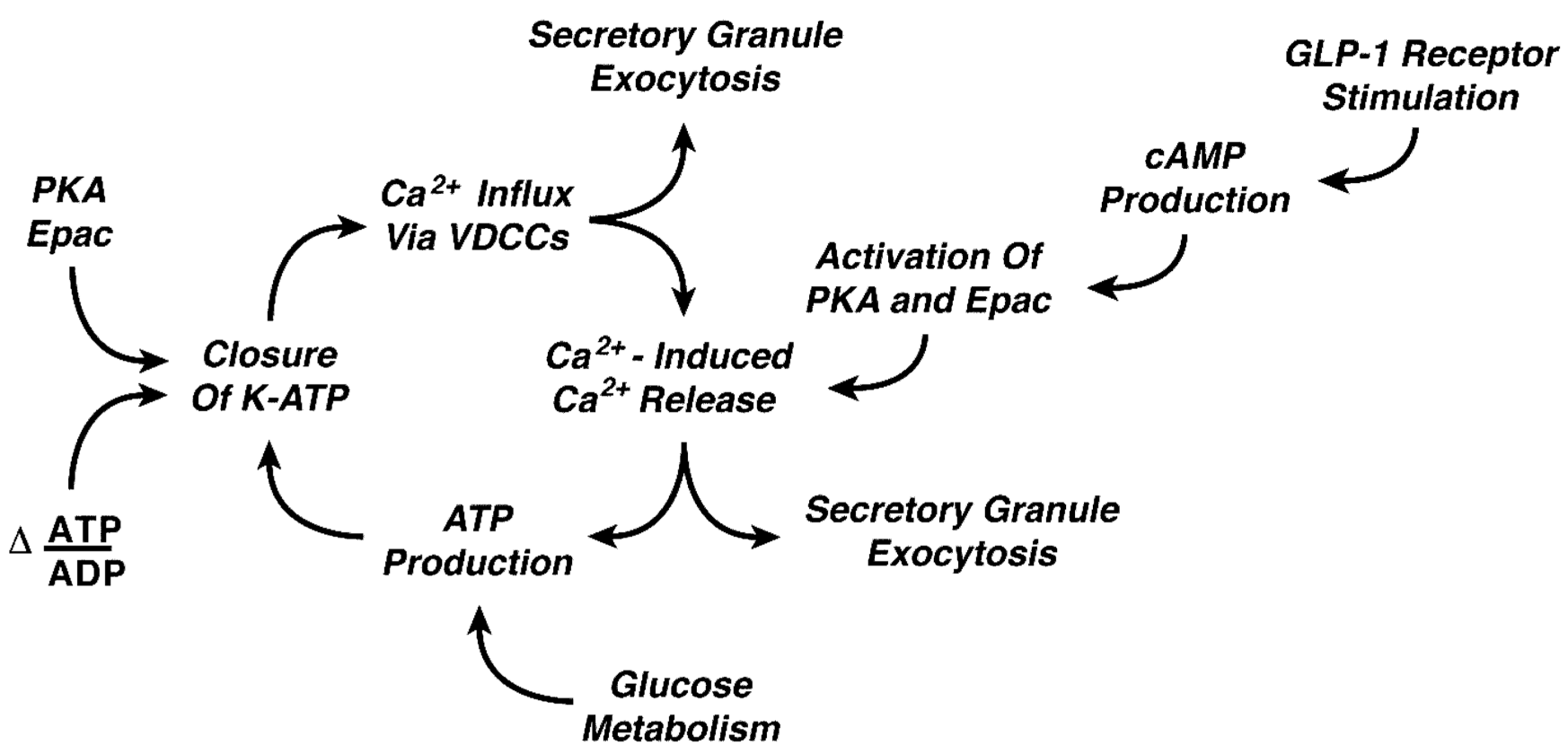

Fig. 4.

"Feed-forward" hypothesis for regulated insulin secretion. GLP-1 activates PKA and Epac by stimulating cAMP production. cAMP-dependent mobilization of intracellular $\mathrm{Ca}^{2+}$ via CICR generates a $\mathrm{Ca}^{2+}$ signal that stimulates exocytosis and which also interacts with glucose metabolism to stimulate mitochondrial ATP production. These mitochondria are strategically located at the plasma membrane in close proximity to K-ATP channels. Increased mitochondrial ATP production generates an increase in cytosolic [ATP]/[ADP] concentration ratio, thus inhibiting K-ATP channels. Simultaneously, GLP-1 acts via PKA and Epac to decrease the sensitivity of K-ATP channels to ADP while increasing their sensitivity to ATP. Closure of K-ATP channels produces membrane depolarization and influx of $\mathrm{Ca}^{2+}$ through VDCCs. Entry of $\mathrm{Ca}^{2+}$ is a stimulus for exocytosis and it also initiates additional CICR because intracellular $\mathrm{Ca}^{2+}$ release channels are sensitized by GLP-1. A feed forward mechanism exists because CICR stimulates an additional round of ATP production, K-ATP channel closure, and $\mathrm{Ca}^{2+}$-dependent exocytosis. Note that the ability of GLP-1 to stimulate insulin secretion is dependent on the presence of glucose because glucose serves as the "fuel" for mitochondrial ATP production. 